\title{
The open access tube map
}
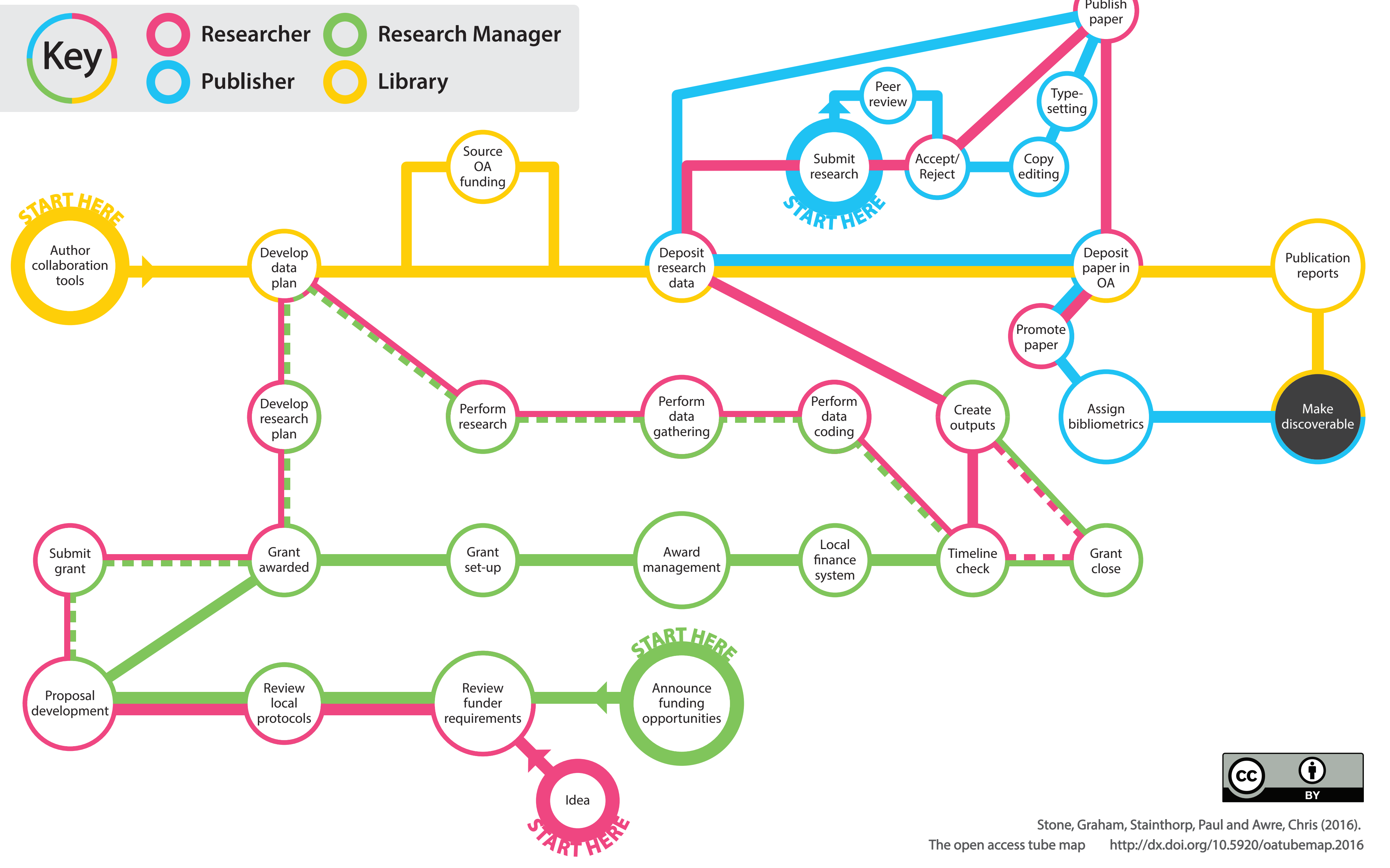